\title{
The Harms of Asking: Towards a Comprehensive Treatment of Sexual Harassment
}

\author{
Michael D. Vhay $\dagger$
}

Commentators have discussed the legal consequences of acts constituting sexual harassment ${ }^{1}$ for some time, albeit with less concern than that shown by many writers on the subject today. In an article that appeared fifty years ago, Calvert Magruder wrote that women "have occasionally sought damages for mental distress and humiliation on account of being addressed by a proposal of illicit intercourse."2 Magruder noted that these actions were rarely successful. Unless the proposal was incidental to a "recognized" tort such as assault, battery, or trespass, recovery was "generally denied, the view being, apparently, that there is no harm in asking."

Over the last ten years courts have found that there is harm in asking-or, more precisely, harm caused by asking. Beginning in 1976 with the district court decision in Williams $v$. Saxbe $e^{4}$ and culminating in the summer of 1986 in the Supreme Court's decision in Meritor Savings Bank, FSB v. Vinson, ${ }^{5}$ the federal courts have found that sexual harassment may constitute sex discrimination. The courts have concluded, for example, that those who make sexual advances in the workplace may violate Title VII if the alleged

$\dagger$ A.B. 1983, Harvard University; J.D. Candidate 1988, The University of Chicago.

1 The definition of sexual harassment used here is based on that stated in Henson v. City of Dundee, 682 F.2d 897, 903 (11th Cir. 1982), citing 29 U.S.C. $§ 1604.11(a)(1981)$ : "[u]nwelcome sexual advances, requests for sexual favors, and other verbal or physical conduct of a sexual nature." Henson noted that such "advances," "requests," and "conduct" could constitute sexual harassment if unwelcome in the sense that the employee did not "solicit or invite" them. It regarded such conduct as "undesirable or offensive." 682 F.2d at 903. This definition is a prior version of that used in the Equal Employment Opportunity Commission's Guidelines on Sex Discrimination, 29 C.F.R. \& 1604.11 (1986). For an examination of the differences, see notes 32-36 below and accompanying text.

${ }^{2}$ Calvert Magruder, Mental and Emotional Disturbance in the Law of Torts, 49 Harv.L.Rev. 1033, 1055 (1936).

3 Id. at 1055.

413 F.Supp. 654 (D.D.C. 1976), rev'd on other grounds as Williams v. Bell, 587 F.2d 1240 (D.C.Cir. 1978).

s 477 U.S. 57, 106 S.Ct. 2399 (1986). [Editors' note: At press time, the United States Reports has assigned a page citation for Vinson but has not published a report of the case. All subsequent citations therefore refer to the Supreme Court Reporter.] 
victim proves that (1) but for the victim's gender, the alleged harasser would not have made the sexual advance, and (2) the advance placed a barrier between the victim and her job.

Not all are satisfied with the courts' recent treatment of sexual harassment, however. On the one hand, some have questioned whether the federal courts should ever hear harassment claims, which resemble tort actions, under the discrimination laws. ${ }^{6}$ On the other hand, others have objected that courts have erred by defining sexual harassment too narrowly: sexual harassment, according to these critics, is more than discrimination. For example, in the employment context, some have argued that an employee who suffers harassment deserves relief beyond mere reinstatement to her job or an injunction to her employer ordering an anti-harassment education program. ${ }^{7}$

This comment will look at the past, present, and future of sexual harassment as an actionable wrong. Part I will examine the history of actions involving sexual harassment, and will attend in particular to the reasons why the early courts refused to recognize sexual harassment as discrimination. Part II will present the practical and theoretical limits of the theory that sexual harassment is merely sexual discrimination. This analysis will show that the same difficulties that hindered the early courts in recognizing sexual harassment as sex discrimination prevent modern-day courts from recognizing harassment as more than sex discrimination; these difficulties include a misunderstanding of the nature of sexual harassment and a discomfort with interfering with matters of sexual conduct. Finally, Part III will suggest ways in which the legal system can overcome the limitations implicit in defining sexual harassment as merely sex discrimination, so as to maintain theoretical consistency, forge a consensus on sexual problems, and provide the appropriate level of relief for victims of sexual harassment.

\section{I.}

A. Before Williams: Harassment is not Discrimination

Until recent times, Magruder's observation that one could solicit with impunity was true. Unless the challenged acts involved an assault or a battery, courts were reluctant to compensate plain-

- See, for example, Vinson v. Taylor, 760 F.2d 1330, 1333 n.7 (D.C.Cir. 1985) (Bork dissenting from refusal to grant en banc hearing).

' See, for example, Comment, A Theory of Tort Liability for Sexual Harassment in the Workplace, 134 U.Pa.L.Rev. 1461 (1986). 
tiffs for harassment. Courts dismissed claims involving unwelcome verbal advances, for example, on the theory that words alone are not actionable unless they are defamatory. ${ }^{8}$ The Kentucky Court of Appeals in Reed $v$. Maley, for example, held that although "[s]ociety and the moral sentiments of the people strongly condemn conduct" like indecent solicitation, there was no principle furnishing a ground for legal redress. ${ }^{10}$ Where there was no physical injury, damages were too hard to prove, too "remote," and too "metaphysical" for courts to assess.

While the courts generally refused actions based solely on verbal harassment, in cases employing traditional tort theories, courts often regarded harassment as an aggravating factor that supported compensation for nonphysical harms and awards of punitive damages. ${ }^{11}$ The courts also sometimes held special classes of harassers, such as servants of public utilities, liable for their illicit proposals. ${ }^{12}$ While the reasons offered by the courts for imposing liability in these cases might not appeal to present-day opponents of sexual harassment, ${ }^{13}$ the courts' allowance of these claims may have been prescient. As Thomas Street noted in 1906,

See, for example, Davis v. Richardson, 89 S.W. 318 (Ark. 1905), and see generally Annotation, Indecent Proposal to Women as Assault, 12 A.L.R.2d 971 (1950). There were some exceptions, however, to the words-alone theory. See, for example, State v. McIver, 231 N.C. 313, 56 S.E.2d 604 (1949) (black male convicted of criminal assault for making sexual proposals to white female); State v. Allen, 245 N.C. 185, 95 S.E.2d 526 (1956) (assault where defendant deliberately and repeatedly expressed his "lustful desires" towards a female while masturbating in his car).

Two states retain criminal laws that specifically prohibit indecent proposals towards women. See S.C.Code Annot. § 16-15.250 (1976) and Va.Code § 18.2-417 (1950). New Mexico has a more general insult statute, see N.M.Stat.Annot. § 30-3-1 (1978), and two other states recognize a right to be free from personal insult, see Cal.Civ.Code $\S 43$ (Deering 1941) and Okla.Stat.Annot. tit. 76, § 6 (1951).

74 S.W. 1079, 5 Ky.L.R. 209 (1903).

1074 S.W. at $1080-81$.

11 See Skousen v. Nidy, 90 Ariz. 215, 367 P.2d 248 (1961) (punitive damages and award for mental suffering, including "shame," appropriate for 65-year-old woman harassed by employer; assault and battery proven); Mitran v. Williamson, 21 Misc.2d 106, 197 N.Y.S.2d 689 (1960) (damages allowed for public disgrace, humiliation, mental and physical distress from obscene phone calls and letter); Edmisten v. Dousette, 334 S.W.2d 746 (Mo.App. 1960) (damages for worsened nervous condition resulting from physical advance). Similarly, in criminal actions, the taking of "indecent liberties or familiarities" with a female, or the purposeful infliction of shame or disrepute, were aggravating circumstances in many state assault and battery laws during this period. See, for example, Maine v. Towers, 304 A.2d 75 (Me. 1973); South Carolina v. Hollman, 245 S.C. 362, 140 S.E.2d 597 (1965).

12 See Restatement (Second) of Torts $\$ 48$ (1965) and cases cited in comments therein.

1s The dissent in Reed urged recognition of Maggie Reed's complaint because " $[t]$ he purity of woman and the sanctity of the marriage relation lie at the basis of our whole social fabric, and attempts to destroy them are grave offenses." 74 S.W. at 1083 (Hobson dissenting). 
The treatment of any element of damages as a parasitic factor belongs essentially to a transitory stage of legal evolution. A factor which is today recognized as parasitic will, forsooth, tomorrow be recognized as an independent basis of liability. It is merely a question of social, economic and industrial needs as those needs are reflected in the organic law. ${ }^{14}$

In the 1960s and 1970s, an unparalleled combination of social, economic, and industrial needs prompted recognition of sexual harassment as an independent basis of liability. The advance of the women's movement encouraged many women to speak out against harassment. Moreover, as women entered the workforce in greater numbers, men began to encounter them in what previously had been male bastions. Some men responded with harassment. ${ }^{15}$ For these reasons, reports of sexual harassment increased, and with them the demands for relief. ${ }^{16}$ These demands coincided with the enactment of the modern civil rights laws. The most important of these laws were the discrimination statutes, particularly Title VII of the Civil Rights Act of $1964,{ }^{17}$ and later Title IX of the Education Amendments of $1972,{ }^{18}$ as well as the amended version of the Fair Housing Act. ${ }^{19}$

The first discrimination law to include sex as a prohibited category, Title VII, did not immediately enhance the prospects of relief for victims of sexual harassment. In fact, as late as the mid1970s, plaintiffs characteristically resorted to traditional legal theories in order to press harassment-related claims. ${ }^{20}$ This was partly because Congress did not pass Title VII as a measure explicitly designed to cope with sexual harassment. In fact, gender was not even included in the original draft of the statute, and, ironically, was added only as an attempt by conservatives to derail the bill. ${ }^{21}$

14 Thomas Atkins Street, 1 Foundations of Legal Liability 470 (1906), quoted in Prosser and Keeton on the Law of Torts 57 n.22 (5th ed. 1984).

15 For more historical background, see Catharine A. MacKinnon, Sexual Harassment of Working Women (1979) ("MacKinnon").

${ }^{16}$ For the actual numbers of sex discrimination suits, see U.S. Equal Employment Opportunity Commission, Annual Reports (published yearly 1968-1982). For a representative collection of articles, see MacKinnon at 295-96 n.176-78 (cited in note 15).

1742 U.S.C. $\S \S 2000 \mathrm{e}$ et seq. (1982).

1820 U.S.C. $\$ 1681$ (1982).

1942 U.S.C. $\S \S 3301$ et seq. (1982).

${ }^{20}$ See Monge v. Beebe Rubber Company, 114 N.H. 130, 316 A.2d 549 (1974) (breach of contract action); Wiley v. Georgia Power Co., 134 Ga.App. 187, 213 S.E.2d 550 (1975) (wrongful termination action); Gates v. Brockway Glass Co., 93 L.R.R.M. 2367 (C.D.Cal. 1976) (action against union for breach of duty of fair representation).

${ }^{21}$ See 110 Cong.Rec. 2577-84 (1964). In 1964, a true anti-sex discrimination constitu- 
When plaintiffs first began to bring sexual harassment claims under Title VII, the courts rejected them. In Barnes $v$. Train, for example, the district court held that despite Congress' desire to strike at the entire spectrum of disparate treatment in employment, a supervisor's retaliation against a female employee for her refusal to submit to his advances was essentially "underpinned by the subtleties of an inharmonious personal relationship."22 No matter how inexcusable his advances were, they were not prohibited by Title VII. ${ }^{23}$ The district court suggested that the supervisor's act of retaliation discriminated not on the basis of the plaintiff's gender, but on the basis of other "personal" factors not prohibited by Title VII.

The district court in Corne $v$. Bausch \& Lomb, Inc. ${ }^{24}$ also focused on the "personal" aspects of sexual harassment. In that case, a supervisor repeatedly made verbal and physical advances towards two female employees who were allegedly forced to quit because of his behavior. The court held that the supervisor's actions arose from the supervisor's "personal urge," which was distinct from Bausch \& Lomb's company policies. Only the latter could provide a basis for a Title VII claim. Further, the Corne court concluded that allowing suits for harassment under Title VII was "ludicrous" for two reasons. First, if the activity in question was directed equally against males, Title VII would not apply. The court inferred from this that Congress had not intended to redress sexual harassment through the discrimination laws. Second, the court believed that if it held this conduct to be discrimination, all "amorous or sexually oriented advances" among employees would become actionable. This would force employers to hire "asexual" employees in order to avoid liability. ${ }^{25}$

In 1976, the year following Corne, two other courts decided that Title VII did not cover sexual harassment, basing their decisions upon a concern for the possibility of an unmanageable in-

ency was nascent. See generally Sarah Evans, Personal Politics (1979). It was not until passage of the Equal Employment Opportunity Act of 1972, Pub.L.No. 92-261, 86 Stat. 103 (1972), codified at 42 U.S.C. $\S 2000$ e et seq., that Congress expressly reaffirmed its opposition to sex discrimination in the workplace. "[D]iscrimination against women is no less serious than other prohibited forms of discrimination, and ... it is to be accorded the same degree of concern given to any type of similarly unlawful conduct." See Employment Opportunities Enforcement Act of 1971, Sen.Rep.No. 92-415, 92d Cong., 1st Sess. 7 (1971).

${ }_{22} 13$ F.E.P Cases 123, 124 (D.D.C. 1974), rev'd as Barnes v. Costle, 561 F.2d 983

(D.C.Cir. 1977) (ultimately finding discrimination).

${ }^{23} 13$ F.E.P Cases at 124.

24390 F.Supp. 161 (D.Ariz. 1975), vacated without opinion, 562 F.2d 55 (9th Cir. 1977).

${ }^{25} 390$ F.Supp. at 163-64. 
crease in the number of claims. The court in Miller $v$. Bank of America $^{26}$ began by characterizing the sexual advances of the plaintiff's supervisor as "unauthorized isolated sex-related acts" that could not constitute the acts of Bank of America. Only if the employer had actively or tacitly approved personnel policies requiring sexual favors as a condition of employment would there be a Title VII violation. Otherwise, the court reasoned, if harassment were discrimination, then every firing or failure to promote could be turned into a discrimination action. Further, because it felt that sexual attraction was pervasive, the Miller court doubted its capacity to distinguish actual illegal harassment from harmless flirtation-yet another reason to anticipate an unmanageable increase in cases. ${ }^{27}$

The district court in Tomkins v. Public Service Electric \& Gas $\mathrm{Co}^{28}$ reached a similar conclusion, but by different reasoning. Title VII was "not intended to provide a federal tort remedy for what amounts to physical attack motivated by sexual desire" simply because the attack occurred in the workplace, not in a "back alley." Permitting such actions would open the floodgates, creating a need for " 4,000 federal trial judges instead of some $400 . "$ "29

By the mid-1970s, however, the courts could no longer maintain that there was no harm in asking. They had to admit that there was harm, but most insisted that there was no law against it. Sexual harassment could not be discrimination on the part of the employer, they reasoned, because sexual advances were "personal," or at least something that one could rarely attribute to an employer. They also invoked the lack of explicit congressional intent to make sexual harassment a form of prohibited sex discrimination. And even if sexual harassment were discrimination, the courts argued, it was a type that was too hard to judge, seemingly impossible to remedy, and potentially too widespread for the system to handle. In raising these objections, however, the courts disregarded the purposes of the very statutes they so earnestly cited in barring these actions-statutes that prohibit discrimination without regard for the difficulties of particular cases, the ease of remedy, or the magnitude of the problem that they address. 1979)

28418 F.Supp. 233 (N.D.Cal. 1976), rev'd on other grounds, 600 F.2d 211 (9th Cir.

27418 F.Supp. at 236.

${ }^{28} 422$ F.Supp. 553 (D.N.J. 1976) ("Tomkins I"), rev'd, 568 F.2d 1044 (3d Cir. 1977) (ultimately finding actionable harassment).

29422 F.Supp. at 556, 557. 


\section{B. After Williams: Harassment is Discrimination}

In order to win their discrimination actions, sexually harassed plaintiffs realized that they had to convince the courts that harassment involved more than "personal" acts. Victory in this effort came when plaintiffs confronted the courts with the most flagrant examples of harassment. Such was the case in the first district court decision to recognize sexual harassment as a Title VII violation, Williams v. Saxbe. Diane Williams, an employee of the Department of Justice, refused her supervisor's sexual advances. Her supervisor retaliated with annoying comments, unfavorable reviews, and unwarranted reprimands. While maintaining that "nonemployment related personal encounters" were not actionable under Title VII, the court held that it was improper for a supervisor, whom the court regarded as an agent of the employer, to retaliate against an employee for refusing to comply with an illegitimate, discriminatory employment condition-in this case, a demand for sexual favors. ${ }^{30}$

Soon thereafter, courts began holding that plaintiffs made out a prima facie case of sexual harassment if they proved facts similiar to those involved in Williams: an employer or a supervisor's demand for sexual favors in return for a job, a promotion, or other benefits. ${ }^{31}$ It made sense that Title VII protected victims of this kind of conduct, which became known as "quid pro quo" harassment. Title VII explicitly forbids discrimination in the terms, conditions, and privileges of employment. ${ }^{32}$ In quid pro quo cases, an employer or his agent explicitly ties the terms, conditions, and privileges of the victim's employment to factors which are arbitrary and unrelated to job performance.

The Title VII quid pro quo cases opened the door for harassment actions under other discrimination statutes. In Alexander $v$. Yale University, ${ }^{33}$ the court determined that an educational institution's failure to respond to complaints of sexual harassment constituted grounds for a Title IX action. State courts likewise adopted the Williams rationale and held quid pro quo harassment to be illegal under state discrimination statutes, including those

so Williams, 413 F.Supp. at 662.

31 See, for example, Garber v. Saxon Business Products, 552 F.2d 1032 (4th Cir. 1977); Barnes v. Costle, 561 F.2d 983 (D.C.Cir. 1977); Tomkins v. Public Service Electric \& Gas Co., 568 F.2d 1044 (3d Cir. 1977) ("Tomkins II"); Heelan v. Johns-Manville Corp., 451 F.Supp. 1382 (D.Colo. 1978).

3242 U.S.C. \& $2000 \mathrm{e}-2(\mathrm{a})(1)$.

${ }^{33} 459$ F.Supp. 1 (D.Conn. 1977). 
prohibiting housing discrimination..$^{34}$ Similarly, in several cases where state government employers were found to be quid pro quo harassers, courts allowed $\S 1983$ actions for violation of federal rights. ${ }^{35}$

In addition to applying the Title VII quid pro quo analysis to claims brought under other statutes, the courts began to define harassment more broadly. For example, in Wright v. Methodist Youth Services, Inc., the court held that quid pro quo harassment on the part of a male homosexual supervisor was illegal. ${ }^{36}$ The EEOC's promulgation of guidelines on sexual harassment, however, prompted a more sweeping extension of the strictures of the discrimination laws. ${ }^{37}$ The guidelines first codified what the courts

34 Most of these claims were brought under state counterparts to Title VII. See, for example, Coley v. Consolidated Rail Corp., 561 F.Supp. 645 (E.D.Mich. 1982) (pursuant to Mich.Comp.Laws Annot. §§ 37.2101 et seq. (West 1985)); Howard Univ. v. Best, 484 A.2d 958 (D.C.App. 1985) (pursuant to D.C.Code $\$ \S 1-2501$ et seq. (1981)).

A claim of illegal quid pro quo harassment by a landlord was made in Chomicki v. Wittekind, 128 Wis.2d 188, 381 N.W.2d 561 (1985). There the plaintiff, a tenant suing under Wisconsin's fair housing law, Wisc.Stat.Annot. $\$ 101.22$ (West 1973), won a verdict against a landlord who had evicted her for having refused his advances. The court declared that the purposes of the employment discrimination and fair housing laws were the same; "only their fields of operation differ." 381 N.W.2d at 564. A similar claim under the federal Fair Housing Act, 42 U.S.C. $\$ \S 3601$ et seq. (1982), was upheld in Shellhammer v. Lewallen, No. 843573 (6th Cir. July 31,1985 ) (available on LEXIS).

${ }^{35}$ See Huebschen v. Dept. of Health \& Social Services, 547 F.Supp. 1168 (W.D.Wisc. 1982). Huebschen, a male, filed various claims against a state agency and his female supervisor, charging harassment which violated Title VII. He sought relief under both Title VII and 42 U.S.C. $\S 1983$ (1982). Huebschen based his § 1983 claim for compensatory and punitive damages on two theories. First, he argued that by violating Title VII, the state became liable to him under the federal laws provision of $\S 1983$. Second, he argued that by intentionally discriminating against him on the basis of sex, the state denied him equal protection-independent of its duty under Title VII not to discriminate against him on the basis of sex. The trial court ordered the supervisor to pay $\$ 25,000$ in damages based on the first theory and did not address the second.

On appeal, the Seventh Circuit affirmed the trial court's acceptance of the first theory, but ruled that since Huebschen could not sue his supervisor in her individual capacity under Title VII, a $\$ 1983$ action based on a Title VII violation could not state a cause of action against her. Huebschen v. Dept. of Health \& Social Services, 716 F.2d 1167, 1170-71 (7th Cir. 1983). The court then examined Huebschen's equal protection claim. While accepting the theory behind the claim, the court determined that Huebschen was not harassed because he was a man, but rather because he was his supervisor's former lover-a group that was not a protected class. Id. at 1171-72.

36 511 F.Supp. 307 (N.D.Ill. 1981). See also Joyner v. AAA Cooper Transportation, 597 F.Supp. 537 (M.D.Ala. 1983), aff'd, 749 F.2d 732 (11th Cir. 1984) (male homosexual supervisor harassed male worker).

${ }^{37} 29$ C.F.R. $§ 1604.11$ (1986). The EEOC's definition of sexual harassment is somewhat confusing, however. The guidelines were intended to explain what behavior constitutes discrimination under Title VII. See 45 Fed.Reg. 25024 (1980). In its first draft of the guidelines, the EEOC described sexual harassment as "unwelcome behavior." It then stated three criteria that separated advances that established a "purely personal, social relationship 
had already held, that quid pro quo harassment in the workplace violates Title VII. But then the EEOC stepped further. Reading the word "condition" in Title VII more broadly than any court in a sexual harassment case had, the EEOC held that discriminatory harassment could stem not only from a superior's actions, but also from coworkers' actions. ${ }^{38}$ The EEOC claimed that its broader reading aligned sexual harassment law with that applied to racial, religious, and national origin harassment. ${ }^{39} \mathrm{~A}$ person would be illegally discriminating when his behavior had "the purpose or effect of unreasonably interfering with an individual's work performance or creating an intimidating, hostile, or offensive working environment."

This new category of harassment became known as "environmental" harassment. By actively or constructively permitting his workplace to be polluted with sexual harassment, an employer is held to have created a discriminatory condition-the very harm that Title VII seeks to correct. In the past, victims of environmental harassment had been unable to prove their claims under the discrimination statutes if they lacked proof of an abuse of power by an employer, or proof of a discriminatory institutional policy. ${ }^{41}$ Following publication of the EEOC's guidelines, however, the courts eagerly extended Title VII to prohibit environmental harassment occurring in the workplace. A state court took the lead. In Continental Can Co. v. State of Minnesota, the Minnesota Supreme Court held that an employer was responsible for the harassment of one employee towards another when the employer knew or should have known of the harassment but failed to take timely and appropriate action to prevent or remedy it. ${ }^{42}$

without a discriminatory employment effect" from those that discriminated. Id. The final draft gives the impression, however, that "unwelcome behavior" becomes harassment only when it discriminates. 29 C.F.R. $\$ 1604.11$ (1986). The EEOC is correct that this behavior is actionable when it results in different terms, privileges, or conditions of employment, but it is wrong to suggest that this behavior is not harassment when it is not discriminatory. Much that can be characterized as harassment will escape the sanctions of the discrimination laws, as the Supreme Court and other courts recognize. See Meritor Savings Bank, FSB v. Vinson, 106 S.Ct. at 2405-06, and Henson, 682 F.2d at 903.

${ }^{38} 29$ C.F.R. \& 1604.11(d).

${ }^{39}$ See 45 Fed.Reg. 25024 (1980). See also Bundy v. Jackson, 641 F.2d 934, 944-45 (D.C.Cir. 1981); Henson, 682 F.2d at 902-903; Comment, New EEOC Guidelines on Discrimination Because of Sex, 61 Boston Univ.L.Rev. 535, 543-46 (1981). This "alignment" has not been perfect however. See notes $72-74,80-81$ and accompanying text.

40 29 C.F.R. $\S 1604.11(a)(3)$ (1986).

41 See, for example, Corne, 390 F.Supp. at 163 (Title VII does not prohibit environmental harassment); Alexander, 459 F.Supp. at 3 (barring Title IX environmental claim).

12297 N.W.2d 241, 248 (Minn. 1980). The state based its action on Minnesota's statu- 
The EEOC's view of sexual harassment triumphed in Meritor Savings Bank, FSB v. Vinson. ${ }^{43}$ The Supreme Court held that environmental sexual harassment is a form of sex discrimination prohibited by Title VII when it is so severe or pervasive that it affects the terms, conditions, or privileges of a person's employment. "Without question," wrote Justice Rehnquist,

when a supervisor sexually harasses a subordinate because of the subordinate's sex, that supervisor "discriminates" on the basis of sex ... . [Similarly], [n]othing in Title VII suggests that a hostile environment based on discriminatory sexual harassment should not be likewise prohibited. ${ }^{44}$

On this point, the Court was unanimous. The evolution that this statement represents, from Train's view that harassment is an outgrowth of inharmonious personal relationships to a recognition that many forms of harassment are discriminatory, is nothing short of remarkable. And it took only twelve years.

II.

The course of sexual harassment law under the discrimination statutes has been one of ever-widening interpretation. The courts have covered much ground, and one can expect that they will further expand the legal definition of sexual discrimination. One can anticipate, for example, the courts' application of the environmental harassment reasoning to claims brought under other discrimination statutes apart from Title VII. ${ }^{45}$ In their efforts to respond

tory analog to Title VII, Minn.Stat. $\$ 363.03$, subd. 1(2)(c) (1978). The court followed Title VII case law in interpreting the act. Continental Can, 297 N.W.2d at 246-8. The Minnesota legislature subsequently codified the Continental Can decision. See Minn.Stat. $\S 363.01$, subd. 10(a) (1986 Supp.).

ts 106 S.Ct. 2399 (1986). Ironically, by the time the Supreme Court examined the EEOC guidelines in Vinson, the EEOC seemed to be reconsidering some of its words. See the Brief for the United States and the Equal Employment Opportunity Commission as Amici Curiae, Meritor Savings Bank v. Vinson, No. 84-1979 (Dec. 11, 1985) ("Brief for EEOC") (suggesting that the Court adopt, among other things, a rule that plaintiffs suing employers for hostile environment be required to exhaust internal grievance procedures).

44 106 S.Ct. at 2404-05 (emphasis in the original).

${ }^{45}$ As noted in the text accompanying notes 33-35 above, cases brought under other discrimination laws typically follow Title VII's lead on sexual harassment. A recent Title IX case, for example, has allowed an environmental discrimination claim in an education setting. See Moire v. Temple University School of Medecine, 613 F.Supp. 1360, 1366-67 (E.D.Pa. 1985), aff'd, 800 F.2d 1136 (3d Cir. 1986). By contrast, because plaintiffs can plead intentional discrimination toward a class under $\S 1983$ (see note 35 above), courts recognized environmental discrimination claims earlier under the equal protection clause than under Title VII. See Woerner v. Brzeczek, 519 F.Supp. 517 (N.D.Ill. 1981). In these cases, while there initially was some dispute as to what level of environmental harassment 
to the problem of sexual harassment, however, the courts have overlooked legitimate questions. In doing so, they have perpetuated some of the myths about harassment. Part II of this comment will address two broader questions about the law governing sexual harassment: does the current legal treatment of sexual harassment fully serve the purposes of discrimination law, and does discrimination law adequately address the harms of sexual harassment?

\section{A. Are Courts "Bootstrapping" Sexual Harassment Claims from Discrimination Statutes?}

In his dissent from the D.C. Circuit's denial to grant an en banc rehearing in Vinson, Judge Robert Bork criticized the general trend of sexual harassment cases as unlimited, wide-ranging excursions into matters outside the scope of the discrimination law. "Title VII," Judge Bork wrote, "was passed to outlaw discriminatory behavior and not simply behavior of which we strongly disapprove." ${ }^{46}$ Here Judge Bork echoed the language of the early courts which had refused to entertain sexual harassment claims on these very grounds. Were these courts in fact correct? Are sexual harassment cases just "bootstraps" on discrimination statutes, happily stretched out by judges who "strongly disapprove" of aggressive sexual behavior?

To answer this question, one must begin with the language of the statute. Title VII states that it is "an unlawful employment practice for an employer . . . to discriminate against any individual with respect to his compensation, terms, conditions, or privileges of employment, because of such individual's race, color, religion, sex, or national origin."47 The statute does not define "discriminate," but the term must, at a minimum, include decisions to favor or disfavor one person relative to another based upon prohibited classifications. The Supreme Court has described this type of discrimination, labelled disparate treatment discrimination, as "the most easily understood type of discrimination."48

amounts to intentional discrimination, Vinson seems to have made this showing easier. See Bohen v. City of East Chicago, 622 F.Supp. 1234, 1246-47 (N.D.Ind. 1985) (decided before Vinson) (city not liable for intentional discrimination merely because it failed to act on plaintiff's complaints of harassment), aff'd in part and rev'd in part, $799 \mathrm{~F} .2 \mathrm{~d} 1180,1185-87$ (7th Cir. 1986) (decided after Vinson) (quid pro quo harassment, knowledge of environmental harassment, and failure to enact anti-harassment policies or to investigate complaints constitutes discrimination).

¿6 Vinson v. Taylor, 760 F.2d at 1333 n.7 (Bork dissenting).

472 U.S.C. $\S 2000 \mathrm{e}-2(\mathrm{a})(1)$.

${ }^{48}$ International Brotherhood of Teamsters v. United States, 431 U.S. 324, 335 n.15 
Where does sexual harassment fit in? The core of the typical harassment victim's claim is that she has been treated less favorably than her male counterpart-in other words, it is a disparate treatment claim. But if disparate treatment is the most easily understood type of discrimination, then why was it so difficult for the early courts to understand that sexual harassment constituted discrimination? Is it that the early courts were blind, but now we see?

Yes and no. The early courts recognized that harassers were treating some persons differently from others. They stumbled at the next step of the inquiry: what motivated the harassment and was it impermissible? Today, the chief inquiry in most disparate treatment cases is whether there was an invidious motivation. The question, "Did the defendant intentionally decide to treat the individual less favorably on the basis of race, sex, or other prohibited grounds?" is so important in the typical disparate treatment case that the Supreme Court in McDonnell Douglas v. Green divided the burdens of production on this question into three parts: First, the plaintiff must demonstrate that the circumstances surrounding her treatment give rise to an inference of unlawful discrimination. If this demonstration is made, it creates a rebuttable presumption, one that forces the defendant to state a legitimate, non-discriminatory reason for his action. The plaintiff can then rebut the defendant by demonstrating that his excuse is a pretext for discrimination. ${ }^{49}$ While the plaintiff has the ultimate burden of proof of intentional discrimination, ${ }^{\text {s0 }}$ the McDonnell Douglas scheme allows the judge or jury to find discriminatory motivation on the basis of inferential, as opposed to direct, evidence.

Although the early courts had the tools with which to probe the harasser's intent, the courts did not put them to good use. They would not recognize that the intent to engage in sexual relations with an employee contains the intent to discriminate. In Train, the court suggested that an inharmonious personal relationship, not the plaintiff's gender, was the motivation behind the unfavorable treatment. ${ }^{51}$ In Tomkins $I$, the court stated that sexual desire prompted the harasser, and to probe his intent further would require the courts to craft rules that would be judicially im-

(1977).

49 411 U.S. 792, 802-04 (1973).

so See Texas Dept. of Community Affairs v. Burdine, 450 U.S. 248, 253 (1981).

51 See note 22 and accompanying text. The Seventh Circuit in Huebschen made a similar inquiry in assessing the plaintiff's claim of intentional discrimination, with the same result. See note 35 . 
prudent and unenforceable. ${ }^{.2}$ The courts in these cases, along with those in Corne and Miller, ${ }^{53}$ denied relief because they concluded that the motives underlying sexual harassment had little to do with prohibited gender classifications.

One can posit two potential justifications for the early courts' unwillingness to see sexual harassment as discrimination. One reason, the courts' reluctance to enter the fray, withers in the face of the mandate of the discrimination laws. If a plaintiff proves that her employer treated her differently on the basis of a prohibited ground, then the courts must hold that employer liable under Title VII-even if such a result would "inevitably" lead to the need for four hundred, four thousand, or four million trial judges. Certainly there are times when a court should construe a statute so as to avoid a ridiculous result. That practice dates back to Blackstone. But Blackstone coupled this principle of statutory interpretation with other tools of construction such as legislative purpose, plain meaning, subject matter, and context. ${ }^{54}$ Unfortunately, not one of the early cases employing the "ridiculous results" rationale used any of the other tools of statutory interpretation. Moreover, the unmanageable deluge of sexual harassment suits that the courts feared has not materialized.

The second possible reason for the early results is more intriguing, for it embodies a problem that might survive the Supreme Court's decision in Vinson. Many of the early courts sincerely stated that sexual harassment has little to do with gender lines-that sexual expressions are the result of "personal" forces presumably inherent in one's biological, chemical, or psychological nature. Sustained studies of harassment, however, have proven that this belief is largely incorrect.

The first theorists who studied sexual harassment explained that the practice was rooted in class perceptions. One theory, articulated by Lin Farley in $1978^{\mathrm{s5}}$ and given greater focus by Catharine MacKinnon, describes harassment as "the unwanted imposition of sexual requirements in the context of a relationship of unequal power." "Tse central problem of harassment is, in MacKinnon's view, "the use of power derived from one social sphere to

${ }^{52}$ See note 28 and accompanying text.

${ }^{53}$ See notes 24 and 27 and accompanying text.

s4 See William Blackstone, 1 Commentaries *59-61.

ss Lin Farley, Sexual Shakedown: The Sexual Harassment of Women on the Job (1978).

${ }^{B 8}$ MacKinnon at 1 (cited in note 15). 
lever benefits or impose deprivations in another."'67

A second explanation of harassment, one growing out of a series of empirical studies of working women by Barbara Gutek and others, describes harassment as part of a larger problem of "sexrole spillover"-the inappropriate use of gender roles in the workplace. $^{.8}$ Gutek gives three reasons why such spillover occurs. First, sex roles are more basic cognitive categories than are work roles. Second, many women choose, or are forced to adopt, a stereotypical sex role at work. Some will act like a flirt, for example, in order to be accepted at the workplace. Third, many men are uncomfortable with women in a work role, and as a result many revert to familiar sex roles. Regardless of the reason, however, when sex roles are injected into the workplace, sexual expressions often follow. ${ }^{59}$ When these expressions lack mutuality and present a barrier to work, they become harassment.

Gutek's findings show that harassment is tied to gender. Perceptions of sex roles informed by gender stereotypes, coercion to assume a stereotypical role, and lapses into stereotypical behavior all invoke gender lines-the very thing that the discrimination laws prohibit. ${ }^{80}$ The early cases thus reveal a basic misunderstanding of sexual harassment. In light of what is now known about sexual harassment, the argument that sexual harassment is merely personal breaks down.

The Williams court and its progeny, however, did not immediately grasp the reasons for the earlier courts' failure to see discriminatory intent in sexual harassment. Although the Williams court characterized harassment as an illegitimate condition, it did not hold that the sexual advance itself violated Title VII-rather, the

${ }^{87}$ Id. Those who share MacKinnon's views state their case in two ways. One is that in particular contexts, sexual harassment reinforces the organization's hierarchy, which is typically male-dominated. The second description is related: sexual harassment is an expression of the larger inequitable distribution of power throughout society in favor of males. For a useful summary of these positions, see Barbara A. Gutek, Sex and the Workplace 8-15 (1985) ("Gutek").

ss Gutek developed her theory because predictions based on the MacKinnon model were incongruent with the results of attitudinal studies of sexual harassment in the workplace, particularly on the question of why harassers expressed sexual interest. Gutek at 15. Many of the themes developed by Farley and MacKinnon resonate in Gutek's work, however. Gutek found, for example, that sex-role spillover was higher in work environments where occupations, jobs, or work groups were not integrated. Gutek at 129-51.

so Gutek at 15-18, 66-68 (cited in note 57).

so Although voluntary assumption of a sex-role might be a different matter, it may be possible to put aside this objection. Given the pervasiveness of sexism in American society, a truly voluntary choice may be impossible. 
supervisor's retaliation was the court's key concern. ${ }^{61}$ It was not until the D.C. Circuit reviewed the Train decision in Barnes $v$. Costle that a court began to find discriminatory intent in the sexual advance itself. "The vitiating sex factor," stated the court, stemmed from the imposition by Barnes' superior of "a condition which ostensibly he would not have fastened upon a male employee. . . . But for her womanhood, from aught that appears, her participation in sexual activity would never have been solicited. . . . [I]t is enough that gender is a factor contributing to the discrimination in a substantial way." ${ }^{\text {"62 }}$ Barnes' refusal precipitated retaliation. Since her sex was a significant element behind the invitation, and since refusal of the solicitation prompted retaliation, gender was a substantial factor behind the retaliation, and the harassment constituted a violation of Title VII. ${ }^{63}$

With its shift in focus toward the sexual advance, the court in Costle created a logical framework that effectively ended further debate over the harasser's intent in sexual harassment cases. ${ }^{64}$ The Eleventh Circuit reflected this development five years later in Henson v. City of Dundee. ${ }^{65}$ The court in Henson formally listed the elements of what it saw as the prima facie Title VII sexual harassment action, and the majority of sexual harassment deci-

61 Williams v. Saxbe, 413 F.Supp. at 660-62. Even on remand, the court remained concerned with abuse of employer power. See Williams v. Civiletti, 487 F.Supp. 1387, 1389 (D.D.C. 1980).

${ }^{62} 561$ F.2d 983, 989 n.49, 990 (D.C.Cir. 1977) (footnote omitted).

-3 Id. at 990. The appeals court rejected the lower court's holding that Barnes' membership in the class of those who had spurned the supervisor's advances, and not her sex, was the factor prompting retaliation. See also notes 22-23 and accompanying text.

64 The debate since Costle has been largely over employer liability for an employee's prohibited conduct. See, for example, Ludington v. Sambo's Restaurants, Inc., 474 F.Supp. 480 (E.D.Wisc. 1979) (no employer liability unless employer actively or tacitly sanctioned practice); Neidhardt v. D.H. Holmes Co., 21 FEP Cases 452 (E.D.La. 1979), aff'd 624 F.2d 1097 (5th Cir. 1980) (no liability if employer ignorant of supervisor's actions or if, upon learning, employer takes appropriate action); Henson v. City of Dundee, 682 F.2d 897 (11th Cir. 1982) (employer liable if (1) supervisor abuses powers that employer has granted to him or (2) employer knew or should have known of hostile environment created by supervisor); Vinson, 106 S.Ct. at 2407-09 (declining to issue definitive rule on employer liability, but suggesting that common law agency principles are applicable).

See also Note, Sexual Harassment and Title VII: The Foundation for the Elimination of Sexual Cooperation as an Employment Condition, 76 Mich.L.Rev. 1007, 1025-31 (1978); Note, Sexual Harassment Claims of Abusive Work Environment Under Title VII, 97 Harv.L.Rev. 1449, 1460-63 (1984); Note, Employer Liability for Coworker Sexual Harassment Under Title VII, 13 N.Y.U.Rev.L. \& Soc.Change 83 (1984); Note, Employer Liability Under Title VII for Sexual Harassment After Meritor Savings Bank v. Vinson, 87 Colum.L.Rev. 1258 (1987).

es 682 F.2d 897 (11th Cir. 1982). 
sions since 1982 have adopted the court's approach. ${ }^{66}$ The elements of the Henson test are:

(1) A belongs to a protected group (that is, A is a man or a woman).

(2) B subjected A to unwelcome sexual harassment.

(3) B would not have harassed A "but for the fact of [A's] sex." $" 67$

(4) B's harassment affected a term, condition, or privilege of A's employment. ${ }^{68}$

(5) A's employer was responsible for B's act. ${ }^{69}$

The Henson analysis comes close to serving the purposes of discrimination law, but it is not perfect in its theory or application. As the Supreme Court stated in Griggs v. Duke Power Co., "[w] hat is required by Congress is the removal of artificial, arbitrary, and unnecessary barriers to employment where the barriers operate invidiously to discriminate on the basis of racial or other impermissible classification." Only the first, third, and fifth Henson elements serve this goal. Under the first element, A must establish her membership in a protected class. The third element requires $\mathrm{A}$ to meet the accepted standard of causation for discrimination cases, one that allows a plaintiff to prevail even if unprohibited factors partially motivated the disparate treatment. ${ }^{11}$ Under the

${ }^{60}$ For recent cases, see Meritor Savings Bank, FSB v. Vinson, 106 S.Ct. at 2406; Moylan v. Maries County, 792 F.2d 746, 749, 750 (8th Cir. 1986); Jones v. Flagship Intern., 793 F.2d 714, 719-22 (5th Cir. 1986); Highlander v. K.F.C. Nat. Management Co., 805 F.2d 644, 648 (6th Cir. 1986).

${ }^{87}$ Henson, 682 F.2d at 903-04. The but for test is adopted from Costle. See 561 F.2d at 990-91. The test was another of the federal courts' formulations of the standard of causation under Title VII, and was much stricter than those previously used. See Mark S. Brodin, The Standard of Causation in the Mixed-Motive Title VII Action: A Social Policy Perspective, 82 Colum.L.Rev. 292, 308-10 (1982).

${ }^{68}$ Henson held that in quid pro quo cases, any affect on the terms, conditions, or privileges of employment met this fourth element. 682 F.2d at 909 . For environmental harassment, the harassment had to be "sufficiently severe and persistent to affect seriously the psychological well-being" of the employee. Id. at 904.

69 For example, B was A's employer, B was an agent of A's employer, or A's employer knew or should have known of B's act. Id. at 905 . But see note 64 for the current debate on employer liability.

70 401 U.S. 424, 431 (1971).

71 Mark Brodin suggests that the courts should bifurcate causation analysis into one standard for liability, another for relief. Brodin, 82 Colum.L.Rev. 292 (cited in note 67). See also Michael J. Zimmer and Charles A. Sullivan, The Structure of Title VII Individual Dis- 
fifth element, A must establish employer liability, a necessary proof under Title VII since that statute targets only the conduct of employers, labor organizations, and employment agencies.

By contrast, the second and fourth Henson elements fail to further the goals enunciated in Griggs. The allegation and proof of unwelcomeness, which the Court in Vinson called "[ $t]$ he gravamen of any sexual harassment claim," $"$ raises two concerns. First, Vinson, Henson, and the EEOC guidelines do not explain why a victim of this form of discriminatory harassment, as opposed to racial, religious, or national origin harassment, must prove that the offensive activity was unwelcome. The McDonnell Douglas burden of proof analysis does not mandate such a showing, nor does Title VII. Further, most areas of the law do not require a victim to anticipate her antagonist's defenses in her prima facie case, and Title VII is no exception. Welcomeness in this context is most analogous to a justification for the defendant's act, an issue which the $M c$ Donnell Douglas scheme requires the defendant to raise. ${ }^{73}$ The plaintiff should not bear the burden of rebutting the defendant's affirmative defense in her prima facie case.

In its brief in Vinson, the EEOC argued in favor of unwelcomeness as an element of the plaintiff's prima facie case. To justify placing this burden on the sexual harassment plaintiff, the agency asserted that sexual harassment differs from other classbased harassment because some sexual expressions are normal in the workplace. The EEOC thus concluded that special rules are warranted so as to avoid intrusions into "purely personal, social relationships." "The EEOC argued that courts must insist that plaintiffs demonstrate unwelcomeness in sexual harassment suits in order to "ensure that sexual harassment charges do not become a tool by which one party to a consensual sexual relationship may punish the other."75

The EEOC's argument in Vinson illustrates that the Henson unwelcomeness test is at root the product of an outdated stereotype. As Susan Estrich points out, the notion that people, chiefly women, misuse legal protections against sexual invasions to accuse the innocent is quite old. The justification has been repeatedly

parate Treatment Litigation: Anderson $v$. City of Bessemer City, Inferences of Discrimination, and Burdens of Proof, 9 Harv.Women's L.J. 25, 45 (1986).

72 Vinson, 106 S.Ct. at 2406.

73411 U.S. at 802-4.

${ }^{74}$ Brief for EEOC at 13 (cited in note 43).

76 Brief for EEOC at 15 (cited in note 43). 
used to impose greater burdens of proof on victims of alleged sexual invasions. ${ }^{76}$ While the issue of consent cannot be ignored entirely in sexual harassment cases, the moment the courts begin creating exceptions to discrimination law, they risk frustrating its purposes. To require a showing of unwelcomeness in the prima facie case out of an unsubstantiated fear of spurned lovers' suits amounts to judicial resistance to the purposes of the discrimination laws.

Moreover, it is unlikely that this novel criterion was developed as a time saving rule-that is, if women have a propensity to welcome sexual advances, then the courts could conserve judicial resources by placing the burden of production concerning welcomeness on the plaintiff. One could speculate that the courts have placed the burden of proof of unwelcomeness on the victim of sexual harassment for many of the same reasons that the law traditionally required rape victims to prove lack of consent. ${ }^{77}$ But many states now place the burden of proof of consent in rape cases on the accused..$^{78}$ Many of the rationales for this change are applicable in the sexual harassment context. By focusing on the accused's conduct, rather than the victim's, the law recognizes that in some situations, particularly those in which the accused holds an advantage over his victim, the task of proving lack of consent may be difficult.

In addition to improperly allocating the welcomeness issue to the plaintiff, the Henson "unwelcomeness" element has a second problem: its subjectivity. The court defines unwelcome "in the sense that the employee did not solicit or incite [the conduct], and in the sense that the employee regarded the conduct as undesirable or offensive." This definition not only raises the affirmative defense problem noted above, but it also requires the victim to prove her subjective response to the harasser's act-something which is (again) a judicial creation that is not mandated by the discrimination laws. Moreover, this approach might also disadvantage defendants if a plaintiff regards as undesirable conduct that most would find unobjectionable.

Perhaps more importantly, there is the complication of unwilling submission to sexual advances. The sexual harasser may view

76 Susan Estrich, Real Rape 5 (1987).

77 See id. at 5, 8, 29-41, 57-59.

78 See, for example, Ill.Rev.Stat. ch. 38, $\S 12-13,12-17$ (a) (1985) (consent is a defense to criminal sexual assault; proof of lack of consent is not an element of the offense).

79 Henson, 682 F.2d at 903. 
submission as "welcoming" his behavior. From the perspective of the sexual object, the victim merely is choosing the lesser of two evils: enduring harassment or suffering the consequences. Even at the early stages of sexual innuendos and relationships, an employee may fear the repercussions of rebuffing or disappointing the more powerful sexual aggressor. This hypothetical is not farfetched, and it easily demonstrates the difficulties a victim has in proving unwelcomeness.

Some of these subjectivity problems resurface in the fourth element of the Henson test, which requires a showing that B's harassment affected a term, condition, or privilege of A's employment. In keeping with the EEOC guidelines, the courts in workplace environmental harassment cases have required a plaintiff to show that the harassment had "the purpose or effect of unreasonably interfering with an individual's work performance or creating an intimidating, hostile, or offensive working environment."so This has led courts in sexual harassment cases to inquire into an employee's subjective response to harassment, raising conceptual problems that are not a part of most other types of discrimination cases. If the EEOC Guidelines on Sexual Harassment truly codified the then-existing law on racial and national origin harassment, the objection to the subjectivity of Henson's fourth element would apply to racial, religious, and national origin harassment cases as well as sexual harassment cases. But, curiously, it is not clear whether current racial, religious, and national origin harassment cases follow the same scheme that the Henson court adopts. ${ }^{81}$

The preferred approach would be to adopt a reasonable worker standard. This would ensure even-handed liability and deterrence in all working environments. In Rabidue v. Osceola Refining Co., Judge Newblatt argued that if courts had to determine the reasonableness of the alleged harassment, they would have to consider things such as the nature of the employment environment,

80 29 C.F.R. § 1604.11(a) (1986).

81 See Walker v. Ford Motor Co., 684 F.2d 1355, 1359 (11th Cir. 1982) (adopting fourth element of Henson test in race case); Gilbert v. City of Little Rock, Ark., 722 F.2d 1390, 1394 (8th Cir. 1983) (finding racial harassment where environment "significantly and adversely affects the psychological well-being of an employee"); Erebia v. Chrysler Plastic Products Corp., 772 F.2d 1250, 1256 (6th Cir. 1985) (same); Minority Police Officers v. City of South Bend, 617 F.Supp. 1330, 1352-53 (N.D.Ind. 1985), aff'd, 801 F.2d 964 (7th Cir. 1986) (adopting same standard at first, but hinting at an objective "excessive and opprobrious" test); Weiss v. United States, 595 F.Supp. 1050, 1056 (E.D.Va. 1984) (adopting objective test in religion case). Some courts, however, have opted for an objective standard in sexual harassment cases. See, for example, Volk v. Coler, 638 F.Supp. 1555, 1559 (C.D.III. 1986). 
the educational background of the alleged harasser and his victim, the physical characteristics of the workplace, and even the victim's reasonable expectations. Newblatt argues that such an inquiry qualifies Title VII: "the standard for determining sex harassment would be different depending upon the work environment." $\mathrm{He}$ continues:

Indeed, it cannot seriously be disputed that in some work environments, humor and language are rough hewn and vulgar. Sexual jokes, sexual conversations and girlie magazines may abound. Title VII was not meant to-or can-change this. It must never be forgotten that Title VII is the federal court mainstay in the struggle for equal employment opportunity for the female workers of America. But it is quite different to claim that Title VII was designed to bring about a magical transformation in the social mores of American workers. ${ }^{82}$

Newblatt pushes his point too far. Title VII and other discrimination laws cannot help but transform our social mores, as they prohibit actions stemming from certain disfavored views of racial, ethnic, religious, and gender groups. But he is correct to argue that a subjective standard of conduct would allow the courts to consider factors that would lower the tolerances for sexual aggression. Such a version of a "reasonableness" test would essentially expose plaintiffs to the defense of assumption of risk. But Title VII does not allow its "risks" to be assumed. Rather, the statute requires the eradication of discrimination. Thus courts must establish objective criteria for objectionable harassment, and hold employers liable regardless of the traditional environment.

An argument against applying a subjective analysis to the "terms and conditions" factor can be made from the defendant's perspective as well. If the factor allowed for subjective judgments, defendants could be held liable for actions toward "particularly sensitive" individuals, actions that would not amount to a violation of the law if perpetrated upon "tougher" individuals. This tort principle of taking the victim as you find him is out of place in an area of the law that determines liability for decisions based on group differences, rather than individual ones. To the extent that the discrimination laws address problems that are largely social and systemic, and not individual, subjectivity is out of place.

In sum, the courts' demand for proof of unwelcomeness from

${ }^{82}$ Rabidue v. Osceola Refining Co., 584 F.Supp. 419, 430 (E.D.Mich. 1984), aff'd 805 F.2d 611 (6th Cir. 1986). 
the victim of sexual harassment and the courts' willingness to examine the subjective feelings of the victim distinguish sexual harassment from other discrimination law actions, despite the courts' declarations that harassment is simply another form of discrimination. Nowhere else in discrimination law do the courts approach a problem so solicitously, demanding such a high level of moral blame before finding liability..$^{\text {s3 }}$

Why such selective treatment? One further example may highlight the reasons. The third element of the Henson test requires $\mathrm{A}$ to allege that $B$ would not have harassed her but for A's membership in a class. Commentators have described this but for test as a strict standard. ${ }^{84}$ In practice, the courts have reduced the necessary showing to a simple inquiry into sexual orientation. Thus, A need only state that heterosexual B would not have harassed A had $A$ not been a member of the opposite sex, or that homosexual $B$ would not have harassed A had A not been of B's gender. But if B is bisexual, harassing both sexes, A cannot pass this test. Many courts have observed that, under this formula, a bisexual harasser would escape liability entirely. ${ }^{85}$

Sexual harassment case law is, to say the least, not replete with instances of bisexuals harassing with impunity. ${ }^{86}$ But one's emotional response to the possibility that a harasser could escape liability is instructive. When the courts look only to sexual orientation in applying the but for test, they assume that the harasser's orientation indicates his motivation. Usually this is a correct assumption: since the discrimination laws require the courts to determine if the harasser based his decision as to whom to harass on a prohibited classification, and since sexual orientation implies a preference for one gender over the other, the harasser's orientation

${ }^{83}$ The current EEOC explicitly recognizes this, and believes that it is necessary. See notes 74-75 and accompanying text.

st See, for example, Brodin, 82 Colum.L.J. at 309 (cited in note 67); Zimmer and Sullivan, 9 Harv.Women's L.J. at 45 (cited in note 71).

${ }^{8 s}$ See Barnes, 561 F.2d at 990 n.55; Henson, 682 F.2d at 905 n.11; Vinson, 760 F.2d at 1333 n.7 (Bork dissenting).

This sort of problem can arise in any harassment-as-discrimination action, sexual, racial, or otherwise. In the race context, see Bradford v. Sloan Paper Co., 383 F. Supp. 1157 (N.D.Ala. 1974) (harasser argues that he treats everyone badly, regardless of race, color, religion, or national origin).

${ }^{88}$ If the problem arose, liability for the harasser is not inconceivable. There would be no liability only if one adheres to the orientation analysis. One could abandon that analysis in a case involving a bisexual, and question why the harasser chose one victim over another. If gender stereotypes were a but for cause of the decision (for example, if the bisexual harasses his female secretary because he believes "that's what female secretaries are for"), then the bisexual would have discriminated illegally. 
often will explain why he chose as he did. But the riddle of the bisexual harasser remains. One would think as a result that, in order to solve this riddle, courts would reject the sexual orientation analysis and substitute in its place a test that would impose liability for any decision based on sexuality.

The problem is that the concern of the discrimination laws in sexual harassment cases is not discrimination based on sexuality, but disparate treatment based on gender. The EEOC justified extending Title VII's protection to sexual harassment victims because it concluded that it was wrong to bar those claiming harassment based on one prohibited criteria, sex (gender), while allowing those harassed on the basis of other prohibited criteria, such as race, to bring their claims. ${ }^{87}$ Henson states the analogy explicitly: "Sexual harassment which creates a hostile or offensive environment for members of one sex is every bit the arbitrary barrier to sexual equality at the workplace that racial harassment is to racial equality."88

But the Henson court went on to perpetuate the ambiguity felt by so many courts that had preceded it. While it justifies Title VII suits for sexual harassment by analogy to racial harassment, the Henson court uses the word "sexual" elsewhere in its opinion to mean not "of or relating to gender," but of or relating to sexuality. ${ }^{80}$ The majority of courts continue to define the term "sexual" in sexual harassment suits brought under discrimination theories in this way. ${ }^{90}$ The difference has had practical consequences. In Turley $v$. Union Carbide Corp., the plaintiff argued that her male supervisor had harassed her-not in a sexual manner, but by pick-

${ }^{87}$ See 45 Fed.Reg. 25024.

ss Henson, 682 F.2d at 902.

so For example, in defining unwelcome sexual harassment, the Henson court called on the EEOC guidelines, which emphasize the sexual, rather than gender-based, nature of the conduct. "Sexual advances, requests for sexual favors, and other verbal or physical conduct of a sexual nature" are cited as examples of sexual harassment. Id. at 903, citing 29 C.F.R. $\S$ 1604.11(a) (1981).

90 See, for example, Meritor Savings Bank, FSB v. Vinson, 106 S.Ct. at 2406 (unwelcome advance is the gravamen of the complaint); Katz v. Dole, 709 F.2d 251, 254-55 (4th Cir. 1983); Coley v. Consolidated Rail Corp., 561 F.Supp. 645, 649 (E.D.Mich. 1982). There are some exceptions. See Bell v. Crackin Good Bakers, Inc., 777 F.2d 1497, 1503 (11th Cir. 1985) (" $[\mathrm{H}]$ arassment can be of at least two kinds: (1) threatening, bellicose, demeaning, hostile or offensive conduct . . . because of the sex of the victim of such conduct; or (2) 'unwelcome sexual advances' generally known as a 'quid pro quo' ground."); Horn v. Duke Homes, 755 F.2d 599, 605 (7th Cir. 1985) (Title VII creates incentive for employers to prevent the hiring and retention of sexist supervisors); Heelan v. Johns-Manville Corp., 451 F.Supp. 1382, 1390 (D.Colo. 1978) (Title VII strikes at disparate treatment based on sex stereotypes; "stereotype of the sexually-accommodating secretary is well documented"). 
ing on her. Since he had allegedly singled her out for this treatment, she argued sexual harassment. The court dismissed the plaintiff's complaint, holding that in the sexual harassment context, " '[s]ex' . . . does not mean gender. Rather, it is used pursuant to its more popular meaning." The court concluded that if a plaintiff alleges asexual disparate treatment, traditional disparate treatment analysis must be followed, not the Henson scheme. ${ }^{91}$

Henson's tendency to treat sexual harassment as sexuality harassment holds at least one advantage over the alternative of treating sexual harassment as gender harassment. By accepting that sexuality is a legitimate inquiry, the Henson view allows courts to use sexual orientation as a proxy for intent. As discussed above, it is easier for a court to rely on the harasser's sexual orientation than to probe the harasser's actual motives. Plaintiffs under the Henson scheme will be able to prove discriminatory causation easily, unless the harasser is a bisexual.

One cannot deny, too, that the Henson view has an emotional appeal as well: By focussing on sexual orientation, Henson indicts harassers for their harassment, and not just their discrimination. That the Henson approach satisfyingly addresses both wrongs explains why the notion of the liability-free bisexual harasser is upsetting. Practically speaking, the emotional appeal of Henson-that the courts are attacking two forms of "morally blameworthy" conduct, harassment and discrimination-partially explains why there are departures from discrimination theory in sexual harassment cases. $^{92}$

Because sexual harassment involves a subject that often embarrasses and perplexes American society-sexual behavior-its discriminatory aspects have been accorded special treatment. So while the courts acknowledge that sexual harassment is discrimination based on gender, they continue to perpetuate some of the myths and ambiguities that prevented the courts from understanding, or deterred them from deciding, the sexual harassment cases in the first place. It is in this regard, and this regard alone, that Judge Bork's dissent in Vinson is correct: some of the sexual harassment cases do use the discrimination laws as "bootstraps" for

91618 F.Supp. 1438, 1441-42 (S.D.W.Va. 1985).

${ }^{92}$ Several courts state this explicitly. The Henson court described quid pro quo harassment as extortion. $682 \mathrm{~F} .2 \mathrm{~d}$ at 910 . Other courts claim the need to rid society of shocking conduct. See Howard University v. Best, 484 A.2d 958, 981 (D.C.App. 1984); Arnold v. City of Seminole, Okl, 614 F.Supp. 853, 870 (E.D.Okla. 1985). Another court analogized sexual harassment to prostitution. See Lucas v. Brown \& Root, Inc., 736 F.2d 1202, 1205 (8th Cir. 1984). 
other concerns. This has the effect of both enlarging and constricting the scope of discrimination liability.

Perhaps there is no way to keep sexuality concerns out of a discrimination-oriented inquiry into sexual harassment. But if courts are to attain the goals of the discrimination laws, they must exercise their best efforts to separate sexual from discriminatory offenses. This means that the courts should not manipulate discrimination theories in order to roam unnecessarily into the area of sexual practices. Likewise, they should eschew those parts of the Henson prima facie case that create a standard of moral culpability apart from that established in the discrimination laws themselves.

\section{B. Harassment As More Than Discrimination}

Our examination so far has shown that the law recognizes sexual harassment as gender discrimination. Empirical studies, such as Gutek's, confirm that this recognition is correct. Yet, in many cases the courts have reached this recognition out of a sense of outrage, rather than upon an empirical understanding of sexual harassment as gender discrimination. Some argue that this is wrong-that the federal courts should search only for discrimination, not for sexual immorality. Others object to court intrusions into the individual's "personal" life, which raise (for them) free speech and privacy concerns. ${ }^{93}$

On the other hand, those who wish that the courts would address the problems raised by sexual interaction have their own objections to relying upon the discrimination laws to redress the injuries of harassment. They object that the bootstraps provided by the discrimination laws are too short to remedy all of the harms of harassment. For example, Title VII applies only to defined employers, labor organizations, and employment agencies. It exempts small businesses, private membership clubs, religious organizations, and actions with respect to Communists. ${ }^{94}$ It also declares a

os No defendant has argued in a reported case that his conduct is constitutionally protected. The Rabidue court expressed concern, however, that if Henson allows an inquiry into the reasonableness of "verbal conduct of a sexual nature," a defendant might have a valid First Amendment defense. 584 F.Supp. at 431. See also Snell v. Suffolk County, 611 F.Supp. 521, 528 (E.D.N.Y. 1985), aff'd, 782 F.2d 1094 (2d Cir. 1986) (racial harassment case; concerns about privacy interests suggest that "the courts not become involved in policing what citizens say and do in their homes and at social gatherings"). A greater analysis of constitutionally protected harassment is beyond the scope of this comment.

94 See 42 U.S.C. § 2000 e(b) (small businesses, Indian tribes, and tax-exempt, bona fide private membership clubs other than labor organizations exempted); id. at $\$ 2000 \mathrm{e}$-(1) (reli- 
right to equal treatment only in the terms, conditions, and privileges of employment. ${ }^{95}$ Harassment from a co-worker outside of the workplace, for example, is not actionable under Title VII unless the employer has power over those activities. The other discrimination and civil rights laws have similar subject matter limitations. Section 1983 applies only to state and municipal actions. ${ }^{96}$ Title IX is limited to specific programs that receive federal funds. ${ }^{97}$ The Fair Housing Act exempts dwellings with less than four rental units, and is inapplicable to most sales of homes completed without the services of a broker. ${ }^{98}$

Perhaps more importantly, the discrimination laws vary in their remedies. Title VII, for example, provides only equitable relief. ${ }^{99}$ For the plaintiff in Henson, this meant that once she had left her job, she was not entitled to an injunction against her former employer's practices, nor could she recover for pain and suffering. ${ }^{100}$ Also, punitive damages are not permitted under Title VII. By contrast, in $\S 1983$ and Fair Housing actions, an assortment of remedies ranging from injunctions to punitive damages is available. ${ }^{101}$ Title IX presents the most confusion in this area, with many courts limiting remedies to a cutoff of federal funds or injunctive relief. The Supreme Court, however, has suggested that in Title IX cases involving intentional acts, wider relief may be available. ${ }^{102}$

gious organizations); id. at $\S 2000 \mathrm{e}-(2)$ (f) (Communists).

${ }^{85}$ Id. at $\$ 2000 \mathrm{e}-2(\mathrm{a})(1)$.

${ }^{96}$ Id. at $\S 1983$ (applying to persons who act "under color of any statute, ordinance, regulation, custom, or usage of any State or Territory or the District of Columbia").

${ }^{87}$ See Grove City College v. Bell, 465 U.S. 555, 572-74 (1984).

9842 U.S.C. $\$ 3603(\mathrm{~b})$.

99 42 U.S.C. $\$ 2000 \mathrm{e}-5(\mathrm{~g})$.

${ }^{100} 682$ F.2d at 905 . In the absence of an equitable remedy, the plaintiff may not be entitled to attorney's fees either. See Bohen v. City of East Chicago, 799 F.2d 1180, 1184 (7th Cir. 1986), for cases on both sides of this issue.

${ }^{101}$ Compare 42 U.S.C. $\$ \S 1983$ and 3612.

${ }^{102}$ This confusion arises, in part, from the evolution of Title $\mathrm{XX}$ case law. Congress modeled Title IX on Title VI of the Civil Rights Act of 1964, 42 U.S.C. $\S 2000$ d (1982). Few plaintiffs, if any, have brought harassment suits under Title VI, and so harassment case law under Title IX has had to emerge on its own, albeit in the shadow of Title VI. In Lieberman v. University of Chicago, $660 \mathrm{~F} .2 \mathrm{~d} 1185,1188$ (7th Cir. 1981), the court determined that as a matter of statutory construction, only injunctive and administrative relief, as well as attorney's fees, were available to successful Title IX claimants. But in Guardians Association v. Civil Service Commission of N.Y.C., 463 U.S. 582, 597 (1983), a Title VI racial discrimination action, Justice White noted that while plaintiffs suing on congressional acts passed pursuant to the Spending Clause usually are not entitled to remedies which aim to make the plaintiff whole, in cases of intentional discrimination "it may be that the victim . . . should be entitled to a compensatory award, as well as prospective relief . . . ." Because the plaintiffs in Guardians did not allege intentional discrimination, White's statement is dicta, but his reasoning suggests that the Lieberman decision is wrong. 
The discrimination laws are thus an incomplete solution to the problems that harassment poses. Society's general interests regarding sexual harassment may best be understood by reference to both discrimination and tort law. Through its discrimination laws, society prohibits discrimination where it operates to bar people from opportunities in areas such as employment, housing, and education. The judiciary serves this mandate by determining when statutes have been violated and administering statutory remedies. Society also relies upon the courts, through mechanisms such as tort law, to compensate those who have been unjustly harmed by others, and to dissuade people from engaging in future injurious practices. ${ }^{103}$ The problem with respect to sexual harassment is that the courts have not approached these two different tasks systematically. We thus return to the questions posed to the courts over ten years ago: what is it about sexual harassment that offends societal interests, and what can the legal system do to correct it?

\section{III.}

It should not be surprising that there is confusion over how to remedy sexual harassment. Discrimination arises from complex motives that are both personal and societal. The original thrust of the Civil Rights Act of 1964 was directed only at personal discrimination, in part because Congress itself did not fully understand the problem it sought to correct. Discrimination was seen as a product of "ill-will on the part of some identifiable individual or organization." But within eight years, Congress came to describe the problem as being more systemic than personal. ${ }^{104}$ The tension between these views is understandably greater when the element of sexuality is present. To this extent, the holdings in Train and Williams are both correct: sexual harassment can be both improper personal conduct and discriminatory behavior.

One can isolate the harms more specifically. There are three potential wrongs arising from sexual harassment: (A) it is a form of illegal discrimination, defined as behavior that can impose barriers on the basis of an improper classification-gender-to equal opportunity in socially protected spheres, such as employment, education, and housing; (B) it is behavior that society feels is inappro-

${ }^{103}$ See Prosser and Keeton on the Law of Torts chap. 2 (cited at note 14). See also Richard A. Posner, Economic Analysis of Law \$ 6.15 (3d ed. 1986) (intentional torts constitute a coerced transfer of wealth in a setting of low transaction costs, violating market efficiency principles).

10 Sen.Rep.No. 92-415 at 5 (cited in note 21). 
priate in certain contexts such as public transportation, education and housing; and (C) it is behavior that violates general, ill-defined societal standards of "decency," regardless of context. ${ }^{105}$ Each of these harms should be analyzed separately so that their differences are not lost. There are several reasons why this is critical to proper adjudication and relief.

First, the legal analysis of discrimination and other barriers to equal opportunity is largely a matter of statutory interpretation, while the analysis of torts entails sifting through both statutory and common law principles. The courts balance issues, afford presumptions, and defer to legislatures one way when interpreting statutes, and in another way when expounding the common law. ${ }^{106}$ Second, because society arguably has discrete opinions on each of these harms, judicial commingling of the issues hampers society's ability to discern the law and assert the public values that govern the issues. ${ }^{107}$ Judicial confusion thwarts the goal of coordinate consensus building by the legislative and judicial branches.

A third and related reason for separating the issues is to mitigate juror bias. If, for example, a community feels that fanny slapping is acceptable, but the practice interferes with an individual federal right to equal employment opportunity, the local tolerance of the personal conduct (and the possible reluctance to award damages for it) should not lead to derogation of the employee's federal right. By the same token, absent congressional intent to preempt state or local regulation, the federal law should not be used to intrude upon local definitions of tortious conduct. ${ }^{108}$

${ }^{105}$ Some courts have made similar classifications in cases where plaintiffs have attached tort claims to their discrimination claims. See Stewart v. Thomas, 538 F.Supp. 891, 897 (D.D.C. 1982) (Title VII claim along with pendent claims of assault, battery, and intentional infliction of emotional distress); Shaffer v. National Can Corp., 565 F.Supp. 909 (E.D.Pa. 1983) (discussion of Title VII, Pennsylvania Human Rights Act, and intentional infliction of emotional distress claims); Holien v. Sears, Roebuck and Co., 117 L.R.R.M. 2583 (Or. 1984) (discussion of Title VII, Oregon employment discrimination statute, and wrongful discharge claims); Howard University, 484 A.2d 958 (discussion of D.C. Human Rights Act and intentional infliction of emotional distress claims).

${ }^{106}$ The early courts' concern about a flood of harassment-related litigation is a good example. The amount of potential litigation should be a minor consideration in construing Title VII, as Congress is presumed to have anticipated (or should have anticipated) the judicial costs of the statute when it enacted Title VII and when it amended Title VII in 1972. By contrast, the number of potential suits could be a major consideration in judicial extension of a common law doctrine, as the judiciary is effectively the legislature in that instance.

${ }^{107}$ Some argue that such value discernment should be the key function of the adversary system. See Bruce A. Ackerman, Reconstructing American Law 93-104 (1984).

${ }_{108}$ One can limit the effects of local preferences by reducing the number of subjective elements within the discrimination count, which would otherwise allow for a greater degree 
Finally, separating the causes of action helps society reach the desired level of deterrence and compensation. Under most discrimination statutes, a defendant is strictly liable for his discriminatory conduct, whereas under common law principles of liability, a defendant is responsible only for that tortious behavior which is negligent. The causes of action should be split so as to maintain the proper incentives to sue and to refrain from objectionable conduct.

A suggested model for analyzing sexual harassment is presented below. This scheme permits redress of the three harms of sexual harassment, and avoids some of the problems of the current approach to sexual harassment-problems that can result in over- or under-compensation.

\section{A. Harassment as Discrimination-The Revised Henson Proof}

As discussed in Part IIA, the "unwelcomeness" and "terms and conditions" elements of the Henson analysis diverge from the purposes of the discrimination laws. Although sexual harassment is a peculiar form of discrimination, its peculiarities are simply the sexual factors that are involved in harassment, not any unique twist to the principle of disparate treatment. Thus the courts should not distinguish harassment from other forms of discrimination. ${ }^{109}$

The prima facie case of sexual harassment under the discrimination laws should thus be that for disparate treatment generally, which is:

(1) $\mathrm{A}$ is a member of a protected group.

(2) B intentionally acted with respect to A. ${ }^{110}$

(3) B would not have acted with respect to A but for A's membership in the group.

(4) B's action would have prevented the average member of A's group from achieving equal opportunity in a sphere of interest that the government wishes to protect. ${ }^{111}$

of fact finder bias to enter into the decision.

${ }^{109}$ One writer on the issue of employer liability for sexual harassment makes this same argument for applying traditional standards of vicarious liability for discrimination to harassment suits. See Note, 87 Colum.L.Rev. at 1275-76 (cited in note 64).

110 This element serves to make this a "treatment" case, like McDonnell Douglas, as opposed to an "impact" case, like Griggs v. Duke Power, 401 U.S. 424 (1971). Illegal disparity is proven in the third element.

${ }^{111}$ Ronna Greff Schneider, in Sexual Harassment and Higher Education, 65 Tex.L.Rev. . 
(5) The discrimination statute targets people in B's position.

This statement of the case has two advantages. First, it does what Henson purported to do: that is, align all actions involving harassment. In the racial, religious, and national origin contexts, it is disparate treatment according to the victim's membership in a class that is the issue. The same should hold true for sexual harassment. ${ }^{112}$ This revised analysis sets a common standard for all forms of disparate treatment.

Second, the proposed model removes the unnecessary showing of unwelcomeness. As empirical studies have shown, all of the motivations behind sexual advances in the workplace contain discrimination. To purge the workplace of discriminatory barriers to equal opportunity, it should be presumed that a sexual advance, if it imposes such a barrier, is unlawful discrimination. ${ }^{113}$ Employers should have the same incentives to combat sexual harassment as they have to eradicate other kinds of discrimination. By correctly allocating the burdens of proof, the courts can help maintain the proper level of deterrence. As with other discrimination actions, the defendant will always have the opportunity to assert a defense in order to defeat the presumption of unlawful conduct. Current law, however, begins with the presumption that a sexual advance is permissible until proven unwelcome. ${ }^{114}$ A presumption consistent with the general body of discrimination law is that a sexual advance is discrimination, unless the one making the advance can provide a justification.

\section{B. Advances in Inappropriate Contexts-A New Harassment Tort}

The court in Tomkins I pointed out that Title VII was not intended to give a federal tort remedy for sexual attacks simply because they occurred in the workplace, and not the "back al-

525, 536-39 (1987), concurs in this revision of the fouth element.

112 The Eleventh Circuit may have already recognized this. See the definition of harassment used in Bell, 777 F.2d at 1503, described in note 90.

${ }_{13}$ When one starts from the opposite presumption, one can slip all too easily into reasoning that ultimately subverts the purposes of discrimination law. For example, in Jackson-Coley v. Corps of Engineers, 43 F.E.P. Cases 617, 620 (E.D.Mich. 1987), the court construed "voluntariness" to mean that the victim must show that the advance was unwelcome "in the sense that the employee deliberately and clearly makes her nonreceptiveness known to the alleged offender." Although the court's construction was only dicta, one cannot imagine the same court requiring a black employee, for example, to state "deliberately and clearly" his desire not to be insulted on account of his race.

${ }^{114}$ See notes 72-79 and accompanying text on the unwelcomeness standard. 
ley."11s Congressional intent and the limited remedies under Title VII (namely, its lack of an actual damages provision) support the Tomkins I court's contention: Title VII's concern is discrimination, not tort.

Nevertheless, few could disagree that sexual harassment is often tortious. Tortiousness often depends upon the context in which behavior occurs. For example, consider the difference between unwelcome sexual advances at a singles bar and those in the workplace. Discrimination alone does not explain the intuitive difference. One can posit two possible explanations for the relative appropriateness of the behavior: (1) Being at a singles bar indicates welcomeness, while being at work does not; (2) Society expects greater care to be taken at work, while no such expectation governs conduct at a singles bar.

The first proposition is an incomplete rationale. It may explain why the advance at the nightclub is not so bad. One may go to a club to improve one's chances of receiving an advance. But does one go to work in hopes of avoiding an advance? To be sure, one might not expect or desire an advance at work, but going to work can hardly be treated as an assertion of unwelcomeness.

The second theory better explains the difference between the advance at a nightclub and the advance at the workplace: society imposes a higher standard of care in the workplace than in a bar. This reflects the understanding that in certain situations, power may be allocated so as to exacerbate the harms of objectionable conduct. In quid pro quo harassment cases, for example, the supervisor backs up his request for sexual favors with an express or implied threat of reprisal. One can describe this situation either from the employer's viewpoint, and call it extortion, ${ }^{116}$ or from the employee's position, and call it an imposition of a cruel choice between tolerating the harassment or forfeiting an important benefit. In co-worker environmental harassment, the workplace may not vest one worker with extortionate power over his colleague, but the victim's dependence on her job still may present her with the same no-win choice. ${ }^{117}$ The choice seems less cruel in the nightclub example only because of the (arguably) lesser values at stake: the vic-

118 Tomkins I, 422 F.Supp. at 556.

118 As did Henson, 682 F.2d at 910.

117 Many have noted how the extortion component of sexual harassment makes it odious. See, for example, Note, 76 Mich.L.Rev. at 1007 n.2 (cited at note 64); MacKinnon at 1 (cited at note 15); John B. Attanasio, Equal Justice Under Chaos: The Developing Law of Sexual Harassment, 51 U.Cin.L.Rev. 1, 21-23 (1982); Note, 97 Harv.L.Rev. at 1451 (cited at note 64). 


\section{tim can put up with harassment or find alternative} entertainment. 118

The legal system frequently makes such contextual distinctions. Apart from the discrimination laws, one example is $\S 48$ of the Restatement (Second) of Torts, which states: "A common carrier or other public utility is subject to liability to patrons utilizing its facilities for gross insults which reasonably offend them, inflicted by the utility's servants while otherwise acting within the scope of their employment." The explanation given above as to why society values certain contexts over others explains the special instance of $\S 48$ liability: common carriers and public utilities provide highly valued services; forcing a patron to run a gauntlet of abuse to obtain those services presents the patron with a choice that society will not tolerate. ${ }^{119}$

Section 48 provides a model for determining liability for sexual harassment in inappropriate contexts. In fact, some of the early sexual harassment cases used theories similar to $\S 48$ to impose liability on the offender. ${ }^{120} \mathrm{~A}$ prima facie case of harassment similar to this theory would be:

(1) A sought to participate in a special activity (e.g. tenancy, ${ }^{121}$ school, ${ }^{122}$ or work $^{123}$ ).

118 Of course, both situations contain imbalances of power, albeit ones of different degrees. The supervisor clearly can withhold a benefit. The lascivious nightclub patron, by contrast, cannot ask the person who rebuffs his advance to leave. But to the extent that other patrons tolerate, if not encourage, the advancer's conduct, the person who rebuffs the advance will have to withdraw-if not to home or another club, at least to another corner of the bar. Thus, one situation seems worse than the other only because of a judgment that work is more valuable than entertainment, not because the imposed choice is warranted in one context and not the other. On a positive note, however, the law helps shape values. Title IX, for example, embodies a judgment that discrimination in athletic programs is as damaging as discrimination in classroom education. See Brenden v. Indep. School Dist., 477 F.2d 1292 (8th Cir. 1973).

${ }^{110}$ See $\$ 48$ comment (a) ("value of the rule lies in the incentive which it provides for the selection of employees who will not be grossly discourteous to those who must come in contact with them;" liability based on "the public duty").

${ }^{120}$ See note 12.

121 The Fair Housing Act, 42 U.S.C. \& 3603(b).

${ }^{122}$ As for education, see Jerry v. Board of Education of the City of Syracuse, 35 N.Y.2d 534, 364 N.Y.S.2d 440, 446 (1974) (teacher slept with student, used profane language in classroom; "conduct directly affects the performance of the professional responsibilities of the teacher" and hence presents grounds for discharge); Kilpatrick v. Wright, 437 F.Supp. 397, 399 (M.D.Ala. 1977) (teacher made advances toward female students; "The sexual improprieties for which [the teacher] is being discharged cannot be tolerated in the classroom. The threat to the healthy mental development of impressionable young minds is obvious.") Micari v. Mann, 126 Misc.2d 422, 481 N.Y.S.2d 967, 970, 324 N.E.2d 106 (1984) (students' claim for intentional infliction of emotional distress resulting from sexual harassment by teacher held to allege outrageous conduct; punitive damages warranted for such "reprehensible" behavior). See also Schneider, 65 Tex.L.Rev. at 550-53 (cited at note 111).

${ }^{123}$ See text accompanying notes 115-18 regarding the special nature of the employment relation in emotional distress actions. 
(2) B harassed A.

(3) B's harassment unreasonably harmed A.

(4) B holds a position with respect to the special activity that creates a duty for B towards people in A's position.

Such a cause of action has several advantages. The first element allows for discussion of what activities should require a stricter standard of freedom from harassment. ${ }^{124}$ So far, employment, housing, and education have stood out as three such special areas of activity. They are unique not merely because Title VII, the Fair Housing Act, and Title IX say they are. The case law involving torts in employment and school demonstrates many instances where the courts have imposed stricter standards of liability out of a sense that these areas are somehow special. If there are additional environments that require this type of protection, ${ }^{125}$ the first element of the cause of action outlined above allows for that future development.

Second, this tort theory provides relief for some victims of sexual harassment who cannot obtain relief under the discrimination laws. Under this scheme, the bisexual harasser is liable, as are others who escape the discrimination laws' subject matter and remedial limitations. The corollary to this imposition of liability is that providers of certain opportunities will have the incentive to keep them free of harassment.

Third, this theory adopts a standard of liability that parallels other emotional interest torts and avoids the strict liability scheme of the discrimination laws. Here the court should examine the subjective factors that were purged in the revised Henson proof, because here the context of the advance is a critical and legitimate aspect of the scheme. Courts also will be able to employ their extensive experience gained from other civil actions in order to avoid the supposedly inherent proof and remoteness problems cited by

124 This represents another instance where clearer judicial discernment of legal issues and values might help legislatures to respond better to societal pressure for reform.

${ }_{125}$ The doctor-patient relationship may present one such context. Malpractice actions currently remedy some of the abuses of this relationship. See Roy v. Hartogs, 81 Misc.2d 350, 366 N.Y.S.2d 297 (1975). Some states have passed statutes to deal with the problem. See Fla.Stat.Annot. $\S \S 401.411(\mathrm{~h}), 466.027,466.028(\mathrm{k}), 490.009(2)(\mathrm{k})$, and 490.0111 (West 1980 \& 1987 Supp.); Minn.Stat.Annot. § 609.343 (West. 1983 \& 1987 Supp.). 
the early courts in assessing damages for the offense of sexual harassment.

One disadvantage of this approach is that judge-made revisions to doctrine, unlike statutory reforms, do not provide potential offenders with advance notice of their liability. While the problem of lack of notice as to groups presently exempted by the discrimination statutes is not troubling-the publicity that the sexual harassment cases generate is too great for one to argue that there is no notice as to the propriety of certain egregious acts of harassment-the lack of notice with regard to the declaration of new special activities is troublesome. Statutory extension would be more prudent, especially given the obscurity of the $\S 48$ cases. ${ }^{126}$

\section{The Outrageous Advance: Reasserting Current Theories}

The final harm to be addressed is that resulting from advances that, regardless of context, violate societal standards of "decency." The most well known tort that addresses such harms is that for intentional infliction of emotional distress. Curiously, employer liability for emotional distress stemming from alleged harassment has been widening almost concurrently with the development of sexual harassment actions under the discrimination laws. The reasons for this, in all likelihood, are the same as those for the increase in discrimination liability in general: an unprecedented increase in numbers of women and minorities in jobs traditionally held by white males, and concomitant changing attitudes about proper workplace conduct.

The traditional elements of the tort of intentional infliction of emotional distress do not suggest that this expansion was inevitable. In defining the tort, $\S 46$ of the Restatement speaks in terms of "extreme and outrageous conduct" causing "severe emotional distress."127 The courts, however, have watered down the Restatement's adjectives, at least in cases involving harassment at the workplace. The landmark case is Alcorn v. Anbro Engineering, Inc. There, a black employee's white supervisor cast racial epithets at

\footnotetext{
${ }^{128}$ At press time, a LEXIS search revealed only two discussions of $\S 48$ in case law. See Williams v. School Dist. of Springfield R-12, 447 S.W.2d 256, 266-67 (Mo. 1969); Dawson v. Zayre Department Stores, 499 A.2d 648, 651 (Pa.Super. 1985). For examples of statutory declarations of special spheres of interest, albeit not for purposes of tort liability, see the statutes listed in note 125 .

${ }^{127}$ Section 46(1) of the Restatement (Second) of Torts states that "[o]ne who by extreme and outrageous conduct intentionally or recklessly causes severe emotional distress to another is subject to liability for such emotional distress, and if bodily harm to the other results from it, for such bodily harm."
} 
him. The employee alleged humiliation, mental anguish, and physical distress. The court noted that while mere insults do not amount to outrageous conduct, "aggravated circumstances" can make insults outrageous. One such circumstance was the employment relation. ${ }^{128}$

One could read Alcorn in one of two ways: either the employment context made the insult actionable, or else the threshold of outrageousness is lower for some insults than for others. Earlier it was concluded that the evil of some activities was that they forced the victim to make a no-win choice. The court in Alcorn does not express such a concern, nor have any of the courts that have granted relief in sexual harassment cases on grounds of intentional infliction of emotional distress. ${ }^{129}$

Thus the cases indicate that the second description of the $\mathrm{Al}$ corn holding-the threshold for outrageousness is lower for some insults than for others-may be the more accurate one. A close examination of the nominally different standards of liability in intentional infliction and discrimination claims bears this out. The standard in intentional infliction cases is "extreme and outrageous" conduct, while the Henson court's discrimination standard is "unreasonable interference." But when claims for emotional injury have accompanied discrimination claims (either pursuant to a discrimination statute that awards actual damages or as a pendent state claim), plaintiffs have won their cases without a rigorous showing that the unreasonable interference amounted to outrageous behavior. ${ }^{130}$ This development suggests that courts recognize sexual harassment as an insult warranting redress even when the conduct at issue is something less than "extreme and outrageous."

The apparent collapse of the outrageousness standard into the unreasonable interference standard is by no means complete. If

${ }^{128} 86$ Cal.Rptr. 88, 468 P.2d 216, 218 n.2, 219 (1970).

120 For cases where both discrimination and intentional infliction occurred, see Rogers v. Loews L'Enfant Plaza Hotel, 526 F.Supp. 523 (D.D.C. 1981); Stewart, 538 F.Supp. at 891; Shaffer, 565 F.Supp. at 909; Howard University, 484 A.2d at 958; Priest v. Rotary, 634 F.Supp. 571 (N.D.Cal. 1986). Only the Priest case included evidence beyond the fact of workplace harassment that lay a foundation for liability under the theory of intentional infliction of emotional distress.

The Restatement suggests that one reason to impose a different standard of outrageousness for a particular group of people may be to remedy situations in which the conduct "arise[s] from an abuse by the actor of a position, or a relation with the other, which gives him actual or apparent authority over the other, or power to affect his interests." The Restatement gives as examples police officers, school authorities, landlords, and debt collectors. Restatement at $\S 46$ comment (e) and Illustrations 5-8.

${ }^{130}$ See cases cited in note 105. 
one could not prove that the discriminatory harassment amounted to an unreasonable barrier to employment, he could not prove that it was extreme. But perhaps our society feels that sexual harassment by an employer, teacher, landlord, or doctor is outrageous in and of itself. If this is true, then plaintiffs who can prove emotional harms should always plead intentional infliction of emotional distress in sexual harassment cases, so as to benefit from society's changing attitudes toward proper sexual behavior and power distributions. Moreover, victims of sexual harassment can play a role in shaping the legal contours of unacceptable sexual advances. Not only does litigation deter offensive conduct, but it serves to raise community awareness of the problem in general. By asserting a claim of intentional infliction of emotional distress, sexual harassment plaintiffs force the legal system to weigh the harasser's conduct against society's view of outrageousness-a standard that is apparently ever changing and responding to developing conceptions of social responsibilities.

\section{CONCLUSION}

The inadequacies in the laws covering sexual harassment stem from many sources. Some are a product of historical twists. Others reflect the problems of relying upon statutes that were not specific or comprehensive solutions to sexual harassment. But most are a result of trying to push sexual harassment into one tidy legal theory. This cannot be done. Sexual harassment reflects both personal and societal difficulties. One must respond to it with measures directed at society and at the person; education is the best tool, with tort remedies following somewhere behind. The public and private arenas both require consensus, however, to achieve the proper result-consensus on which areas should be free of discrimination, which realms must be free from even mild sexual extortion, and what behavior is too outrageous to tolerate.

The courts have made great strides over the last ten years in curbing sexual harassment. They have gone from believing that there is no harm in asking to an understanding that there is harm caused by asking. In so doing, they have implied that there can be harm in the act of asking itself. The next step requires the courts to define that harm and set to the task of preventing and remedying it. 